An Historical Perspective On Diversity Ideologies in the US:

Reflections on HRM Research \& Practice

\author{
Dr. Stella M. Nkomo* \\ Department of Human Resource Management \\ University of Pretoria, South Africa \\ Stella.nkomo@up.ac.za \\ Dr. Jenny Hoobler \\ University of Illinois at Chicago \\ College of Business Administration \\ Department of Managerial Studies \\ jhoobler@uic.edu (email)
}

Paper Accepted for publication in a Special Issue of Human Resource Management Review, Volume 24 (2014)

Edited by Dr. Dianna Stone and Dr. Diana Deidrick

*Corresponding author 
An Historical Perspective On Diversity Ideologies in the US:

Reflections on HRM Research \& Practice

\begin{abstract}
What is the future of diversity research and practice in HRM? In this paper, we examine diversity ideologies in the United States across four distinct eras: white supremacy and sanctioned exclusion of racioethnic minorities before the 1960s, the equal opportunityCivil Rights era of the 1960s, the diversity management/multiculturalism era of the 1980s and 90s, and today's inclusion/post-race era. We argue diversity practices and scholarship can be viewed as enactments of the underlying diversity ideology that dominated in a particular era. Our examination provides insight into how changes in societal beliefs and attitudes about non-dominant racioethnic groups and their status and incorporation into society have influenced the trajectory of diversity practice and research. Knowledge about this historical linkage then allows us to speculate on the future of diversity research and practice. Based on a content analysis of the HRM articles published on diversity from 20002011, as well as global demographic and political trends, we speculate on what the next era of diversity in HRM may bring. In sum, this paper reflects upon the critical turns of the $20^{\text {th }}$ and beginning of the 21 st centuries as a means of summarizing the evolution of research and practice on workplace racioethnic diversity.
\end{abstract}


An Historical Perspective On Diversity Ideologies in the US:

Reflections on HRM Research \& Practice

When human resource management (HRM) scholars and practitioners use words such as diversity, discrimination, multiculturalism, demography, and inclusion, these terms are often fuzzy in meaning, and vary depending on the geographical, cultural, political, and organizational context. The purpose of this paper is to present a United States historical perspective on diversity in the workplace and, specifically HRM researchers' treatment of this topic in the 20th and the beginning of the 21st centuries, in order to understand the progression of HRM's approach to diversity unto present day, and to speculate on a future diversity paradigm. We present diversity research and practice from four distinct eras: the white supremacy and the sanctioned exclusion of racioethnic ${ }^{1}$ minorities before the 1960 s, the equal opportunity-Civil Rights era of the 1960s, the diversity management/multiculturalism era of the 1980s and 90s, and today's inclusion/post-race era.

Some would argue that the passage of the Civil Rights Act of 1964 prohibiting employment discrimination on the basis of race, color, religion, sex, and national origin in the United States was the beginning of the research and practice of diversity in organizations (Nkomo \& Stewart, 2006). Yet others point to 1987 and the publication of Workforce 2000: Work and Workers for the Twenty-First Century (Johnston \& Packer, 1987). While the significance of these milestones cannot be denied, from an historical perspective, both assertions are not fully accurate. Issues of difference and employee diversity in the workplace have a history that predates both events.

Our contention is that to contemplate the future of diversity, and to understand the current language used in the discussion of equality in the workplace, it is essential to

\footnotetext{
${ }^{1}$ Racioethnicity refers to biologically and/or culturally distinct groups. We adopt this term from Cox (2004: 126) who argued that while definitions of race and ethnicity imply a group is either biologically or culturally distinct from another, in reality it is generally both.
} 
understand both the historical ontology (how has diversity been defined and what groups have been included?) and epistemology (what questions have been asked in the research?). A full understanding requires going beyond chronological evolution. As part of taking stock of the historical perspective of diversity, it is necessary to review the dominant ideologies that have influenced diversity scholarship over this time period in the United States. Specifically, we focus on the concept of diversity ideology as a means to understand changes in societal beliefs and attitudes about non-dominant racioethnic groups, their status and incorporation into American society, and their influence on diversity practices and research.

\section{IMPORTANCE OF CONTEXT AND HISTORY}

In the last few years, scholars in the field of organizational behavior and HRM have increasingly called for greater attention to context in conducting and reporting research (Johns, 2001). Johns (2001: 34) implored researchers to pay attention to substantive and methodological context, which serve as a counterpoint to a focus on a single level of analysis as well as function to explain anomalous organizational phenomena. Context refers to stimuli and phenomena that surround and thus exist in the environment external to the individual, most often at different levels of analysis (Mowday \& Sutton, 1993: 198). An important aspect of context is history, which has not always been well incorporated into the field of HRM despite a growing recognition of the importance of management history (Wrege, Greenwood, \& Hata, 1999). The general availability of texts on labor, business, and management history as well as a journal devoted to the latter, the Journal of Management History, all provide excellent sources for its incorporation.

The criticism of ahistoricity can also be made specifically about the study of diversity. Diversity scholars have been strangely silent about the historical roots of diversity, failing to acknowledge its genesis in the early days of the industrialization of America. Workplace diversity has been too often positioned as a new occurrence in organizations despite the fact 
that the history of labor and work in the United States suggests otherwise (cf. Cooke, 2003; Kurowski, 2002). While there are excellent recent reviews of diversity scholarship (e.g., Avery, 2011; Shore, Chung-Herrera, Dean, Erhart, Jung, Randel \& Singh, 2009), most are ahistorical and do not make explicit linkages to the very early presence of diverse groups in the early $20^{\text {th }}$ century workplace and how this was addressed/managed. To achieve the latter, we employ the concept of diversity ideology. The concept of ideology has been used in many different ways and in various disciplines ranging from political ideology to gender ideology. Generally, an ideology refers to a type of belief system (Seliger, 1976). According to Van Dijk (2000: 94), ideological belief systems are not just cognitive but also social and are defined for certain social groups. In other words, ideologies are forms of shared, societal cognition that are fluid and dynamic. Drawing from these general views of ideology, we use the term diversity ideology in this paper to refer to societal beliefs and attitudes about nondominant racioethnic groups, their status, and how they should be incorporated into the society or nation. Reference to diversity ideologies is not new. Deaux, Reid, Martin and Bikmen (2006) examined the effect of the endorsement of social ideologies that support or undermine the position of one's ethnic group on a person's orientation toward collective action. Social dominance theory has been used in some diversity scholarship to make predictions about the relationship between certain ideologies and identification with a group (Sidanius \& Pratto, 1999). Plaut (2002: 85) used the term "models of diversity" to make the observation that such models "represent implicit and explicit systems of ideas, meanings and practices that suggest how groups should include and accommodate one another and how to best organize a diverse society." Plaut (2010) called for diversity scholars to be more explicit in analyzing how these models of diversity help explain current practices and responses to difference. 
Our analysis explores how external forces shaped the dominant racial and ethnic ideologies in the United States over the 20th and the beginning of the 21 st centuries. We examine how ideological shifts inform the move from condoned, overtly discriminatory HRM practices, to affirmative action and equal opportunity, to multi-culturalism and valuing diversity, to inclusion and post-race thinking. As part of this process we name some of the drivers of these ideological changes. To do this we draw upon several theoretical frameworks. Most notably, from a racial perspective, we call on Omi and Winant's (1986: 55) racial formation theory in which they argue: "The meaning, transformation, and significance of racial theories are shaped by actual existing race relations in any given historical period." We incorporate Banton's (1987) theorizing that within any given historical period there exists competing racial and ethnic paradigms. But, within a certain period, one particular racial and ethnic theory should dominate. So prevailing racioethnic ideologies provide society with a framework for understanding the meaning of race and ethnicity and serve to guide scholars in terms of the questions addressed in research as well as guide practitioners in the management of race and ethnicity in the workplace. We use a variety of evidence drawn from the literature on the evolution of HRM, the history of immigrant and racioethnic workers in the U.S. labor force, management history, reviews of diversity management scholarship, and our own content analysis of the diversity articles published from 2000-2011 in the top HRM journals. The latter analysis was undertaken to ascertain the current focus of diversity research in the first decade of the $21^{\text {st }}$ century. Finally, looking at national and global demographic and political trends, we speculate on what the next era of diversity in HRM may bring.

\section{DIVERSITY IDEOLOGY \#1:}

\section{WHITE SUPREMACY, EXCLUSION, AND OVERT DISCRIMINATION}

\section{The Ideology of White Supremacy}


From the birth of the nation until the mid $-20^{\text {th }}$ century, the prevailing diversity ideology in the United States was that of the legitimacy of racial domination and a belief in white supremacy. The ideology of racial domination was centered in the basic acceptance of the idea that there were various races in the world and that these races could be arranged in a hierarchy according to their value (Banton, 1998). The "race"" problem as well as the "immigrant problem" were intertwined with the many social woes exacerbated by dramatic political and industrial changes taking place in the late nineteenth century in both Europe and the United States (Thompson, 2005). At this time, there was much intellectual debate surrounding the nineteenth-century ideas of race and ethnicity and their influence on individuals, groups, and societies (Banton, 1998: 92).

Sustained scientific efforts in Europe and the United States focused on providing scientific evidence for the idea of a qualitative rank ordering of the human races. An enormous amount of effort went into identifying racial traits by measuring various parts of the human body as well as research into the mechanics of genetic inheritance (McKee, 1993). The latter, referred to as the eugenics movement, emerged in the early 1900s as a backlash against the flood of Irish, Jewish, and eastern and southern European immigrants into the U.S. (McKee, 1993). Before this time, the majority of immigrants were from northern and western Europe: This first wave consisted of skilled artisans and industrious farmers who were easily assimilated into society (Gutman, 1973).

The situation was different for the newer wave of mostly unskilled immigrants. Industrialists viewed them as a large pool of cheap labor who could meet the needs of a rapidly growing factory system. However, antipathy towards them arose because of perceived competition with traditional "American" workers and their perceived cultural

\footnotetext{
${ }^{2}$ We place race in quotations to indicate there is no such thing as race in the biological sense. Race is real only in the sense of being a social construction, primarily recognized by physical appearance or phenotype.
} 
inferiority. According to Gutman (1973), the elite nativism that disparaged the traits of the new immigrants was reflected in the popular discourse of the times. For example, the Chicago Post-Mail described immigrants in that city as "depraved beasts, harpies, decayed, physically and spiritually, mentally and morally, thievish and licentious" (Gutman, 1973: 584). Numerous studies were commissioned by the United States government to investigate the effects of immigration on the country. The most infamous of these, the 41-volume Dillingham Commission Report, authored by some of the most prominent social scientists of the times, embraced popular racism and ethnocentrism, particularly in its Dictionary of Races or People. The Dictionary not only provided a categorization of the different races but also made linkages between race, intelligence, and character (Zeidel, 2004). Negative public sentiment towards immigrants as well as the report of the Commission resulted in the passage of The Quota Act of 1921, followed by the Immigration Acts of 1924 and 1929, which placed country-based numerical restrictions on European immigration to the United States (Zeidel, 2004). Also noteworthy is that immigration from China had been prohibited by the earlier, Chinese Exclusion Act of 1882, and Japanese immigration was halted by passage of the Federal Immigration Act in 1923.

Although there were variations in the classification of immigrants, each group was still perceived to be superior to blacks (Fluehr-Lobban, 2006). Within the racial classification systems propagated during the $19^{\text {th }}$ century, blacks were always placed on the lowest rung, and the inferiority of black people had long been a justification for their enslavement. The American Civil War did not change beliefs about white supremacy. Prejudice against the black population remained strong and social discrimination remained rigid in both the South and the North (Foner \& Lewis, 1980). Beginning with the Reconstruction period and continuing until the Civil Rights Act of 1964, blacks were 
subjected to Jim Crow laws intended to ensure their exclusion from certain types of employment and white society.

\section{HRM Practice}

Ideas about white supremacy spilled over to the workplace. What was the human resource management response to diversity during this era? First, it is important to note that formal personnel functions in organizations were established only between 1915 and 1920 (Dulebohn, Ferris \& Stodd, 1995; Kaufman, 2008). Up until this time, factory foremen were largely responsible for human resource management functions. Immigrant laborers in the early days of the industrialization of the United States faced considerable prejudice and discrimination in the workplace (Gutman, 1973). With respect to the new wave of immigrants, owners and factory foremen saw their challenge as transforming a group lacking an industrial ethos into efficient, modern industrial workers (Gutman, 1973). Illustrative of this view is a quote attributed to a New York City manufacturer: "The difficulty with many cigar makers is this. They come down to the shop in the morning, roll a few cigars and then go to a beer saloon and play pinnocio or some other game, working probably only two or three hours a day" (Gutman, 1973: 558). Human resource management practices relied upon fines and explicit work rules prohibiting what were considered to be the bad cultural habits of immigrants. For example, as cited in Gutman (1973: 544), a New Hampshire cotton mill forbade "spirituous liquor, smoking, nor any kind of amusement ... in the workshops, yards, or factories" and promised the "immediate dismissal" of employees found gambling, drinking, or committing any other debaucheries, even during non-work time (Gutman, 1973: 544).

Despite the fact that during slavery black slaves had provided labor in the Southern factories, black workers were generally excluded from factory jobs by foreman and factory management after their emancipation (Foner \& Lewis, 1980; 1981). In the industrial North, 
manufacturing industries remained closed to black workers until the labor shortages of World War I (Gutman, 1973). If employed, blacks were relegated to the dirtiest, lowest-paying jobs in the factory. Historical documents reveal the prevailing beliefs managers held and the arguments against employing black workers. One argument was that the temperament of blacks was naturally unsuitable for factory work. A telling quote comes from an article written by Jerome Dowd, a prominent economist, who was contracted to investigate the suitability of blacks for factory work:

A superintendent of a hosiery mill writes me that some of the Negroes 'are skilful [sic], but have little care about them. Their chief drawback is from their natural disposition to be careless, unconcerned, and indolent, and some of them are much inclined to liquors. As factory hands they are unreliable. The work is too exacting and confining and too regular for them.' (Dowd, 1902: 589)

Based on his field research, Dowd concluded:

He (the Negro) must be established in those occupations which correspond to his stage of development. With the proper industrial footing, he cannot have too much literary or other knowledge. . I think that the avenues should be kept open for any exceptionally endowed Negro to reach the very summit of human attainment, but for the great mass of the race, the most rapid lines of advance lie in the direction of agricultural pursuits (Dowd, 1902: 590).

In a survey on the feasibility of using black labor in the textile mills of the South, a manager categorically stated, “A Negro can't work in a mill. The hum of the machinery would put him to sleep, and if he even got a dollar ahead he would loaf a week" (Literary Digest, 1900: 764). Another reason given by management for not employing black workers was resistance from white workers. The following quote is attributed to the owner of one of the largest cotton manufacturing firms at the time, and sums up the prevailing attitude: "It is undesirable to work white and colored laborers together in the cotton mills partly because there is considerable race feeling and partly because of the social features that would result" (Cited in the report of the United States Industrial Commission VII, 1900: 64). 
Other racioethnic minorities did not escape similar workplace prejudice. John Commons, a notable economist and labor historian of the time, had this to say about the Chinese and Japanese immigrants: "The Chinese and Japanese are perhaps the most industrious of all races, while the Chinese are the most docile. The Japanese excel in imitativeness, but are not as reliable as the Chinese. Neither race, so far as their immigrant representatives are concerned, possesses the originality and ingenuity which characterize the competent American and British mechanic" (Commons, 1907: 131).

While the ideology of white supremacy influenced human resource management practices and attitudes toward the diverse workers of the early $20^{\text {th }}$ century, the dilemma for industrialists was how to maintain white supremacy but satisfy capitalism's need for labor (Takaki, 1979). This problem became more pressing during the production-intensive World War II years. Consequently, some companies drew upon the research from human relations research centers at universities to devise human resource strategies to successfully employ black workers. Historical records from companies like Du Pont and Lukens Steel Company provide insight into HRM practices used to achieve racial integration at this time (Delton, 2007). Two tools companies relied heavily upon echo many of the present-day prescriptions for managing diversity. These tools were linked to the companies' human-relations managerial policy. The first tool was the establishment of personnel offices to perform the initial legwork of integrating and assessing candidates. Personnel officers were expected to be sensitive to black applicants and the possible prejudice of supervisors. Companies often hired black personnel officers because the personnel office was seen as one of the few appropriate white-collar positions for black employees; it was believed that, in being black, they would be in a better position to accurately assess the quality of black applicants. Personnel officers were also responsible for counseling black and white employees and 
conducting workshops and discussions on race relations. Ironically, some research shows personnel officers sometimes hindered integration (Laird, 2006).

A second tool was the education and training of under-qualified black workers and management personnel (Delton, 2007). Training programs for black employees were instituted in tandem with elaborate systems of job specifications and the identification of promotion criteria. While the latter often worked against black workers, companies like Du Pont also used industrial psychologists to examine job specifications and selection tools for racial bias. Industrial Psychology's emphasis on test validation would in fact become one of the most dominant research themes in HRM during the next ideological era, the Civil Rights era. Another aspect of training during this earlier era was the education of supervisors and personnel workers in requisite human relations skills to manage diverse, non-traditional replacement workers (including women) for white men sent to war. Training topics focused on issues of racial tension, sexual tension, and inappropriate behavior (Delton, 2007: 288).

\section{HRM Research}

During this era, race and ethnic issues were considered in some of the earliest Industrial Relations and HRM research. The problem of correcting the presumably strange and poor working habits of immigrants, what to do about black labor, and the workplace conflict arising from racial tensions have an interesting historical research link (Delton, 2007). The Social Sciences Research Council issued a report entitled Survey of Research in the Field of Industrial Relations in 1928 (Kaufman, 1993). Included in its mapping of the domain of the field of Industrial Relations is a study of "fixed racial traits (if any) affecting work viz. alleged laziness of Negro," and "racial cohesion or conflict among workers in industry" (Kaufman, 1993: 14-15). Furthermore, the seminal works of Frederick W. Taylor and Elton Mayo are viewed as some of the earliest research relevant to human resource management practices in the factories of the early $20^{\text {th }}$ century (Dulebohn, et. al., 1995). 
Taylor's works were written during a time of heightened immigration in the United States, and the ethnicity of workers was carefully noted in his famous pig-iron loading experiments (Wrege \& Perroni, 1974). His experiments were consistent with the idea of transforming immigrant workers into efficient factory operators. According to Kurowski (2002), Taylor adopted the stereotypic racial/ethnic beliefs that prevailed at the time and his descriptions of the workers in his experiments bear testimony. There were also data in Mayo's famous Hawthorne studies relevant to differences in social relations, based on ethnicity, gender, and age, but these data did not become part of Mayo's theoretical formulations (Roethlisberger \& Dickson, 1939).

One of the important yet often forgotten aspects of the outcomes of Mayo's research was the ascendancy of a human relations approach as a viable means of managing diversity, particularly in regard to the problem of how to successfully integrate black workers into organizations. The urgency of solving this problem grew out of the need to accelerate the injection of black labor into industries during the World War II production boom. However, an economic need was not the only reason for the urgency of black assimilation. The United States government issued Executive Order 8802 in 1941 that prohibited racial discrimination in hiring, promotion, and firing in government-contracted companies for the duration of the War. The government also established the Fair Employment Practices Commission to enforce the legislation. According to Delton (2007: 276), despite the confluence of government regulations and economic pressure, the following obstacles prevented the smooth integration of blacks into booming wartime factories: "employers' own discrimination, the dearth of qualified African-American workers, exclusionary union policies, fears of workplace strife, a general culture of racism, and white workers' resistance to the idea of working with blacks." Like many other HRM practices, the idea of using human relations as a means to manage racial integration originated with practitioners who recruited a number of 
industrial psychologists and sociologists to conduct research to support their efforts (Dulebohn et al., 1995).

By the end of World War II, University of Chicago, Harvard, Yale, and MIT had all established human relations research centers funded by industrial leaders of the time (Delton, 2007: 272). Corporate sponsors paid the salaries of the researchers and gave them access to their workplaces to conduct research. Researchers at the University of Chicago identified race and ethnicity as key factors obstructing cooperative working relations (Delton, 2007). One of these earliest studies that had race as its main focus was that of Everett Cherrington Hughes, entitled, The Knitting of Racial Groups in Industry, published in 1946. Hughes was one of the researchers enlisted by executives to study the intersection of race and the informal social dynamics of groups. Among his many conclusions, Hughes reported that the group effects found in Mayo's Hawthorne research were moderated by race. Black workers were not welcomed into informal groups, and as "solitaires" in many workgroups, they were not subject to productivity norms (Hughes, 1946).

By the middle of the $20^{\text {th }}$ century, the perceived immigrant problem had decreased. Over time, Euro-ethnic immigrants were able to successfully assimilate into the factory system or, as some scholars note, they became "white" (Ignatiev, 1995; Brodkin, 1998). Yet, the diversity problem remained in respect to the segregation and exclusion of black workers and a handful of other racioethnic minorities, despite the glimmer of change spawned by the passage of Executive Order 8802 and the establishment of the Fair Employment Practices

Commission during World War II. Significant change would only occur with the passage of the Civil Rights Act of 1964, which reflected a shift in diversity ideology from exclusion to equal opportunity.

\section{DIVERSITY IDEOLOGY \#2: EQUAL OPPORTUNITY AND ITS CHALLENGES}

\section{The Ideology of Equal Opportunity}


According to Plaut (2010b), the ideology of equal opportunity crept into contention in U.S. discourse in the famous Plessy v. Ferguson Supreme Court Case of 1896. The black plaintiff challenged Jim Crow laws regarding the segregation of railway travel, which required black and white passengers to travel in separate cars. The court ruled that "separate but equal" did not violate the equal protection clause of the Constitution, asserting the equal protection clause had nothing to do with broader social arrangements, but only equality before the law (Plaut, 2010b: 85). In effect, the Court upheld the idea of white supremacy and although the idea of equality before the law was left in tact, it did not result in the dismantling of inequality and segregation.

The most robust challenges to the ideology of white supremacy were through the legal and social civil rights movements of the 1960s. The first salvo came from the landmark Brown v. Board of Education case where, in 1954, the Supreme Court held that separate was inherently unequal in public education. On the social movement front, civil rights activists challenged the Jim Crow laws of the South through boycotts, marches, and civil disobedience. The liberal doctrine sweeping America fostered a belief that race should not matter in determining opportunities for minorities. Some scholars call this belief an early form of "colorblindness" (Plaut, 2010b). As the idea of equal opportunity gained social momentum, the U.S. government and political leaders constructed legislation to dismantle the systems of inequality that disadvantaged racial minorities. The landmark Civil Rights Act of 1964, the Voting Rights Act, the Immigration and Naturalization Act, as well as the Fair Housing Act, outlawed discrimination based on race and ethnicity as well as other categories of diversity, and signaled a new era in racioethnic relations and attitudes towards diversity in the United States.

\section{HRM Practice}


Despite the new legislation, creating equal opportunity in workplaces remained a challenge for most employers. According to Dobbin and Sutton (1998), because of the ambiguity of the law and the lack of strong enforcement, the laws raised little concern amongst employers. It was only after the landmark Supreme Court case of Griggs v. Duke Power Company in 1971, making even unintentional discrimination unlawful, and the passage of the Equal Employment Opportunity (EEO) Act of 1972, which opened the door for lawsuits challenging discriminatory practices in organizations, that employers heightened their efforts to comply with the new anti-discrimination legislation. One of the major HRM responses was the employment of human resource specialists who were placed in permanent offices and charged with the responsibility to lead and manage company EEO compliance (Dobbin \& Sutton, 1998). According to Edelman, Abraham, and Erlanger (1992), internal EEO offices were set up at the insistence of human resource experts who exaggerated the risk of litigation because they saw an opportunity to enhance their power and professional status. Foreshadowing diversity management proponents' methods of leveraging support by arguing "the business case for diversity" in later eras, EEO specialists during the Equal Opportunity era used a "bottom-line" argument for diversity. That is, to secure management support for EEO, they argued that their employer should pursue compliance to avoid litigation costs (Edelman, Abraham, \& Erlanger, 1992).

\section{HRM research}

The defense used by Duke Power Company in their 1971 Supreme Court case reveals one of the major arguments companies used for not employing or promoting blacks: Blacks were under-qualified or did not perform well on employment tests. As a result of racially discriminatory employment tests being declared unlawful in Griggs v. Duke Power Company, employers' compliance with antidiscrimination laws then became centered on proving that their HRM practices were not discriminatory. HRM research during the late 
sixties and much of the seventies bears testimony to this focus. The passage of Title VII spurred human resource management scholars to explicitly study the effects of race on components of the employment process. Research from this era tended to address three questions: (1) How can affirmative action be achieved? (2) Does racial discrimination exist? and (3) If discrimination does exist, how can it be addressed? (Nkomo, 1997). These research questions resulted in a proliferation of studies documenting discrimination and prejudice in selection, performance evaluation, promotion and compensation, as well as prescriptions for affirmative action compliance and discrimination reduction. Research on affirmative action provided guidelines for how organizations could best institute affirmative action programs (e.g., Hopkins, 1980). In the area of selection, much of the research was confined to surfacing differences in employment outcomes for blacks and whites (e.g., Newman \& Krzystofiak, 1979; Tepstra \& Larsen, 1985), as well as differential validity and adverse impact in employment tests and how to overcome these problems (e.g., Bayroff, 1966; Boehm, 1977; Hunter, Schmidt, \& Hunter, 1979). Other scholars focused on bias and discrimination in performance ratings and evaluation (e.g., Dipboye, 1985; Landy \& Farr, 1980), and still others examined racial differences in affective organizational variables like motivation and job satisfaction (Bhagat, 1979; Gavin \& Ewen, 1974).

But tension arose between equal opportunity (i.e., race should not matter) and raceconscious agendas (i.e., affirmative action is a means of correcting the effects of the ideology of white supremacy). Ironically, the anti-discrimination clause in Title VII was used by critics to shoot down preferential treatment of racioethnic minorities. And commitment to the equal opportunity ideology started to wane in the late 1970s (Plaut, 2010b). In reaction to affirmative action programs, the acceptance of the equal opportunity mandate began to change. Conservatives used the anti-discrimination legislation to argue against racial preference programs by pointing out how race had been used to justify segregation and 
defend Jim Crow laws (Haney-Lopez, 2005). This rather self-serving argument in support of color blindness, which favored majority groups, was evoked both in public as well as legal discourse as the preferred ideology for questions of race and ethnicity in America. Language from Supreme Court rulings on the question of the legality of affirmative action illustrates how color blindness was being used. In his concurring opinion in Adarand v. Pena, Supreme Court Justice Scalia wrote in 1995: "To pursue the concept of racial entitlement-even for the most admirable and benign purposes - is to reinforce and preserve for future mischief the way of thinking that produced race slavery, race privilege and race hatred. In the eyes of the government, we are just one race here. It is American.” Kelly and Dobbin's (1998) analysis of why the ideology of diversity management replaced equal opportunity is relevant. These authors argue that, as more and more challenges were mounted towards affirmative action and preferential treatment of racioethnic minorities, human resource specialists faced the dilemma of how to repackage equal opportunity to make it more acceptable to the white majority.

\section{DIVERSITY IDEOLOGY \#3:}

\section{MULTICULTURALISM/ DIVERSITY MANAGEMENT}

\section{The Ideology of Multiculturalism and Diversity Management}

The idea of multiculturalism grew out of the civil rights (including ethnic and women's equality groups) movements of the 1960s and 70s. There was dissatisfaction from these groups about the lack of progress to end inequality through civil rights legislation. Many immigrants and racioethnic groups felt their expectations about assimilation or integration had not been met (Citrin, Sears, Muste \& Wong, 2001; Glazer, 1997).

The term multiculturalism was coined in Canada, where it was that nation's official policy as early as 1971, and the term gained traction in the United States in the 1980s and 90s. While definitions vary, multicultural ideologies generally encourage recognition and 
appreciation of distinct cultural groups and their experiences and contributions, the maintenance of the culture and cultural identities of those groups, and the sense that no one group's culture is superior or should be privileged (Takaki, 1993). National policies of multiculturalism are pursued through measures such as supporting diverse community associations and cultural activities, monitoring diversity in employment, and tailoring public services to accommodate cultural differences in values, language, and social customs (Vertovec, 2010). While the term multiculturalism has entered the lexicon of the management discipline, it is perhaps more often used in sociology and public policy, to denote a plurality of people in terms of race, ethnicity, and nationality (King, 2005). More popular in the management literature since the mid-1980s has been the use of the term diversity, used to describe the multitude of cultural groups within a certain applicant pool or workforce as in the definition of multiculturalism above, but also inclusive of gender and sexual orientation, disability/ability status, religious affiliation, and age, and the term diversity management, the policies and programs employers used to attract, hire, and retain these groups.

The ideas of multiculturalism and diversity management gained traction at this time because of the shaky, slippery legal foundation for workplace equality. And, while job opportunities had increased for workers from minority groups, a significant proportion of these workers remained relegated to low paying, low prestige organizational positions (Federal Glass Ceiling Commission, 1995). Concurrently, the national population was becoming increasingly diverse. In 1965 , with the passage of the Immigration \& Nationality Act, quotas were lifted on the entrance of certain immigrant populations. So human resource management faced a dilemma (Kelly \& Dobbin, 1998): how to continue to attract and retain needed workers at a time when the legal compliance reasons for promoting a diverse workforce were no longer relevant. 
As well, the Reagan era signified a time of "fatigue" in relation to workplace equality (Ahmed, 2007). The political climate made it more acceptable for employers to turn away from their concern for equal employment for many reasons such as conservative political beliefs, but also the emerging view that EEO programs had not been taken seriously and that they had failed to enact real social change. This time of equality fatigue was characterized by the belief that equal opportunity and affirmative action programs had become dated. And these programs tended to be stigmatized by leaders in that they were thought to alienate members of dominant groups. Scholars have suggested that equal employment rhetoric was mired in negative connotations - associated with inequalities, discrimination, and the histories of struggle — which was "unappealing," and caused organizational actors to feel ambivalent and fatigued about its potential for change (Ahmed, 2007).

R. Roosevelt Thomas, an early diversity consultant, began using the term managing diversity in his work with U.S. Fortune 500 companies in the early 1980s (Kelly \& Dobbin, 1998). Then with the release of the mid-1980s Hudson Institute Workforce 2000 report, and its urgent, crisis-like calls for organizations to become more diverse in preparation for major demographic changes in labor and consumer markets (Lynch, 1997), diversity management became ensconsed in business rhetoric. The discourse turned from compliance to managing diversity, with an inherent focus on the value-in-diversity proposition (Kelly \& Dobbin, 1998), that is, the "business case" for diversity. The positivist idea that "employers of choice" welcomed people from different cultures and backgrounds, and that a company's diverse workforce was a strategic asset, replaced the old civil rights equal opportunity/fear of litigation rhetoric (Vallas, 2003).

While the rationale for affirmative action and equal opportunity were predominantly legal and moral-it's simply "the right thing to do"- the new idea of managing diversity involved an appeal to rationality. Nkomo (1997) situates the appeal to employers to manage 
diversity within the Weberian notion of rationality, whereby employees are selected, hired, and retained, in a sterile, color-blind fashion. Group memberships and identities have no place in this process and are of no consequence. In fact, current conceptualizations of diversity include everyone, even white males, and include an appeal to utilize the talents of all individuals to achieve organizational objectives. Managing diversity became an apolitical, rational call to respond to changing demographic factors with the rational goal of increasing companies' bottom-line (cf. Robinson \& Dechant, 1997). The idea was that companies who effectively managed diversity could attract and retain skilled workers in a competitive, diverse labor market; better address the needs of diverse markets through understanding a diverse customer base; and make better, more creative decisions because of diverse employees' wide range of perspectives (Amason, 1996; Cox \& Blake, 1991; Ely \& Thomas, 2001; Kochan, Bezrukova, Ely, Jackson, Joshi, Jehn, Leonard, Levine, \& Thomas, 2003; Zanoni, Jannsens, Benschop, \& Nkomo, 2010).

\section{HRM Practice}

The diversity management ideology that only companies who could manage and support diverse cultures would have the ability to retain talent and remain competitive, became commonplace. The rush toward a pro-diversity orientation was on in American businesses, and this was enacted through diversity initiatives, i.e., "specific activities, programs, policies, and other...processes or efforts designed for promoting organizational culture change related to diversity" (Arrendondo, 1996). Broadly, the types of diversity management initiatives companies pursued fell into the following categories: 1) concerted minority recruitment efforts; 2) individual development efforts, e.g., sensitivity and appreciating differences training, affinity groups where minority workers could share issues and provide each other with social support during the workday, and specially-tailored development opportunities for high potential minority employees; 3) organizational 
development efforts, e.g., cultural audits to assess progress toward multiculturalism, diversity policy statements, and diversity advisory boards consisting of internal and external consultants; and 4) external/outreach efforts, e.g., targeting qualified minority-owned and operated vendors with purchasing activities, funding research related to minority health and well-being, and sponsoring minority scholarships and community events (Hoobler, Basadur, \& Lemmon, 2007). Diversity management also became the focus of many popular books and diversity management consultants became an occupation that HR professionals as well as academics began to pursue and a professional service that companies began to demand.

Yet practitioners' focus on an ideology of managing diversity through color-blind or at least color-neutral processes, whereby all racioethnic groups are assumed to be equally valued and hold equal status in the workplace, has been problematized by various management scholars (Hoobler, 2005; Nkomo, 1997). An ideology where diversity management programs include "everyone," even privileged groups in organizations, denies the existence of racism, sexism, and other patterns of systematic discrimination. Linnehan and Konrad (1999) decry the "diluting of diversity" in this way, where, in an effort to manage diversity apolitically and non-offensively, low power groups that should gain access and opportunity through diversity management programs do not. For example, diversity training programs that treat personality distinctions such as Type-A personality and, for example, being a Latina, as equally "diverse" categories, deny that identifying with the latter but not the former brings with it systematic barriers to advancement in organizations. Furthermore, while these new, feel-good types of diluted diversity management programs were more palatable to members of the dominant group, they remained unlikely to achieve greater representation of racioethnic minority groups in hiring and promotion--if these were indeed the intended goals of diversity management initiatives (Hoobler, 2005).

\section{HRM Research}


HRM research during this era focused on two main areas: ironically, documenting discrimination in the workplace, and making the business case for diversity. In the first case, despite the turn to positivist rhetoric, the human resource management literature during this time period remained focused on documenting the lack of access to organizational rewards, lower attainment of hierarchical position, and, in general, more negative organizational experiences of racioethnic minorities, usually blacks. So, despite the turn away from the rhetoric of workplace equality, the research still focused on disparities. In the second case, scholars focused concerted effort in trying to substantiate through evidence-based research, practitioners' claims that more diversity means greater bottom-line returns. This idea that diversity was "good for business" influenced the scholarly research. For example, understanding the effects of a variety of identities on group processes and outcomes (for reviews, see Milliken \& Martins, 1996; van Knippenberg \& Schippers, 2007; Williams \& O'Reilly, 1998) was a frequent theme. Establishing the business case was considered both by academics and practitioners as the necessary first step to proper diversity management (Zanoni et al., 2010). Yet, as content reviews of this research attest, the battle to establish the business case, or the "value-in-diversity" proposition, has not been won. Because diversity has been operationalized in so many different ways (relational demography of individuals, teams, and workplaces; deep- versus surface-level; perceived dissimilarity; standard deviations; indices of difference; coefficients of variation; Gini coefficients; faultline strength), and because performance is determined by a host of factors respective of the diversity of employees (e.g., economic forces, the quality of the product and/or service, the legal and regulatory climate, market strategy), findings have been equivocal and inconclusive (Joshi, Liao, \& Roh, 2011).

\section{DIVERSITY IDEOLOGY \#4: INCLUSION/POST-RACE}

\section{The Ideology of Inclusion/Post-Race}


While the focus of multi-culturalism is to retain the distinctiveness of individual cultural groups while these groups co-exist and are equally valued in organizations and nation states, political and thought leaders in many nations have explicitly and implicitly called for an end to this plurality. In writing about the failure of multiculturalism to create the integrated society and institutions the United Kingdom had hoped for, Alibhai-Brown (2000) writes, "our multicultural policies, with the emphasis on ethnic monitoring and on special provision for black and Asian communities seem increasingly divisive and irrelevant to a new generation of young people, and are out of touch with the way our world has moved on" (http://fpc.org.uk/publications/after-multiculture). Critics in academia, the media, and politics point out several problems with this ideology including: the dogged persistence of racism after several decades of implementation, the marginalisation of minorities by keeping them in special "interest groups" in organizations and governments and off of serious policy agendas and out of leadership positions, the pitting of minority groups against one another for funding and other resources, and the perpetuation of tokenistic views of minority groups as insular and never-changing (Vertovec, 2010). Harvard scholar Robert Putnam, based on his interviews of 30,000 Americans in 41 communities, concluded that people in ethnically diverse settings still do not want to have much to do with one other, and that diversity may bring vitality and even creativity, but diversity has a downside: low trust, altruism, and community cooperation and cohesion (Putnam, 2000).

As well, fatigue and current competitions for resources are factors in multiculturalism and diversity management's potential downfall. Like fatigue with the rhetoric of civil rights and affirmative action in the 1980s, scholars have noted a similar societal fatigue with multiculturalism since 2000. Alibhai-Brown (2000) quotes a young black man she interviewed: "I think this kind of thinking is for sad old people." And a young Asian man was equally scathing: "Multiculturalism is a boring word. It is grey and small and domestic. 
It does not include [majority groups]. It does not include internationalism" (http://fpc.org.uk/publications/after-multiculture). As well, in the current climate of inflation, downsizing and layoffs, and the general world economic downturn, organizations and governments are scrambling for the resources they need to maintain solvency. Efforts targeted at recruiting, retaining, and accommodating specific groups, for example, corporate "affinity groups" where blacks or Indians get together during the work day for special coaching or coworker social support, involve outlays of resources that organizations may perceive as too expensive and not directly tied to bottom-line profitability. As well, ordering the necessity of accommodating one specific group over the other (blacks or Latinos?) is likely to lead to conflict between groups and amongst organizational decision-makers. These conflicts are directly oppositional to the intended goals of multi-culturalism.

The idea of a society that has not abandoned the failed ideology of multiculturalism, but has instead evolved beyond the need for it, is perhaps the ultimate form or reincarnation of the ideology of colorblindness (as in challenges to diversity ideology \#2 above) (e.g., Plaut, Thomas, \& Goren, 2009). This post-multicuturalist ideology has been broached by many scholars using many different terminologies. This society would be marked by equal access to education, jobs, and leadership positions; socio-economic status equality between groups; the end of group-based prejudice; and the opening up of power-based social networks in organizations. We contemplate whether this can ever happen, or if this is simply a privileged or utopian view of the world and institutions. Here we summarize conceptual work from other disciplines in this area. On the subject of race, Bonilla-Silva (2006) and Gilroy (2001) delineate modern post-race ideologies, encouraging us to abandon the empty ideas of race as a true marker of distinction between people. Richeson and Nussbaum (2004), from a social psychology vantage-point, have conducted experiments to examine whether "color-blind" approaches to interethnic relations are superior to multicultural 
approaches, where race is considered a decision-making factor. Gilroy (1998) believes that true equality can only come when society disavows the entire idea of race. Many political pundits and scholars alike have advanced the idea that the U.S. is now indeed post-race with the presidential election of Barack Obama in 2008, and that race no longer factors into the public discourse. But, in reality, the political squabbles involving the mention of race and racism continue (Taranto, 2009). And Plaut (2010a) finds that it is more often whites who agree that we are living in a post-race society than do minority group members.

King (2005), from a social policy perspective, sees America as post-multicultural, not in the traditional "melting-pot" sense, but rather in the sense that a wide diversity of group identities are permitted to endure, to change and join together over time, and to be joined by new group-based members. He states that our society, and by extension, our workforce, is uniquely made up of groups whose members are able to support a common vision of the whole despite group divisions (p. 125). King problematizes the idea that new immigrants/cultural groups wish to remain distinct, and reinforces the idea that U.S. culture can absorb new members. From a sociocultural perspective, Plaut (2010) argues that the idea of permeable identities is ingrained in the American culture by way of our history of immigration, but makes for the possibility of an overall American national identity. Plaut's (2010a; 2010b) call for an interdisciplinary diversity science that links social psychology, for example, the research on in-groups and out-groups in one's immediate situation, to the "social structures and cultural meanings within which these immediate situations are embedded" (2010a: 168) can generate evidence-based post-multiculturalism ideologies. From social psychology to anthropology to social policy, the post-multiculturalism ideology has as a main focus the idea of understanding and transcending group identities. The management literature as well has recently begun reflecting a turn toward the tension between individual and group identities — what is being called "inclusion," or the tension 
between uniqueness and belongingness (Shore, Randel, Chung, Dean, Ehrhart, \& Singh, 2011).

\section{HRM Practice}

Diversity practices in the inclusion/post-race era continue to unfold. Many organizations have retained their diversity management initatives from the 1980s and 90s. Researchers have suggested that organizations are continuing on the path of diversity management invitatives, yet do not engage in discussions of how little progress has been made in this regard (Hoobler, 2005). Others suggest that companies keep even fruitless training "on the books" in the hopes that it may shield them from potential lawsuits. "You want to be able to show you're addressing the problem, and don't really care if you're solving it" (Perry, in Grossman, 2000: 49). And evidence points to the fact that current diversity management programs are not solving discrimination: The non-profit research group Catalyst found that $64 \%$ of black women surveyed reported that diversity programs were ineffective in addressing racism (Grossman, 2000).

Post-race diversity initatives begin from the vantage point of all racioethnic catgories being equally ordered and valued in the workplace, that is, they do not address the existence of systematic discrimination. Linnehan and Konrad (1999) would call this the dilution of diversity (see Ideology of Multiculturalism and Diversity Management - HRM Practice above). Furthermore, taking race out of the conversation in diversity training efforts in this way is unlikely to address continued problems of racism in the workplace.

HRM practices in recent years have tended to focus on old diversity management practices while at the same time employing new terminology like the use of the word "inclusion." In fact, the term inclusion first entered into the diversity lexicon from practitioners and has just recently spilled over into academic usage (Mehta, 2000). Roberson (2006: 227-228) argues that the distinction between the two is this: Definitions of diversity 
focus primarily on heterogeneity and the demographic composition of groups or organizations (a la multiculturalism), whereas inclusion deals with employee behavioral involvement and diversity in organizational systems and processes. Yet, she concludes from the results of her quantitative studies that "the move from diversity to inclusion in organizations may primarily represent a change in language rather than a material change in diversity management practices" (Roberson, 2006: 230)—a phenomenon some have called the fallacy of "old wine in new bottles." Nevertheless, HRM diversity practice in this era of inclusion/post-race ideologies is in its infancy and continues to emerge. Yet what does seem to be clear at the present time is a continued focus on colorblindness in HRM practice (Roberson, 2006).

\section{HRM Research 2000-2011}

To understand the breadth of the HRM research topics of study under the period of inclusion/post-race ideologies, we undertook a content review of diversity publications in the top HRM journals from January of 2000 through November of 2011. Using Caligiuri (1999) as a guide to the top $5 \mathrm{HRM}$ journals, but also including the commonly-considered top journal, Human Resource Management, we reviewed diversity pieces published in International Journal of Human Resource Management (IJHRM), Journal of International Business Studies (JIBS), Academy of Management Journal (AMJ), Academy of Management Review (AMR), Management International Review (MIR), and Human Resource Management (HRM). Overall, the diversity articles published in each journal tended to reflect the topical focus of each individual journal. For example, articles on cross-national diversity and expatriates formed the bulk of diversity publications in JIBS and IJHRM, whereas HRM

published the most articles on the formation of and types of HRM diversity policy. Contrary to the shift in ideology toward inclusion/post-race and away from establishing the business case for diversity, a surprising 33 articles out of the total 115 articles (29\%) focused on the 
value-in-diversity proposition, with 26 of these (23\% of all articles) exploring the performance effects of diversity in teams and top-management teams. And, perhaps even more surprising, a good number of contemporary articles returned to a very early concern of the diversity literature: how to best manage a diverse workforce, with a full 33 articles (29\%) focusing on HR diversity policy. So, in the last decade, diversity research epistemology ("the questions being asked") seems to have lagged behind ideology. While the terminology may be new, e.g., inclusion (in Shore et al., 2011) instead of equal opportunity, the focus on the business case and firm practices seems to have remained the same.

\section{THE FUTURE OF DIVERSITY}

To contemplate future turns in diversity ideologies affecting HRM research and practice, we examined external forces shaping the 21 st century. While we identified several, including climate change/the greening of processes and production (United Nations Environment Programme, 2009), and the continued acceleration of the use of technology (SHRM, 2011), we targeted our predictions toward national and international demographic trends.

In the U.S., one in five Americans will be over 65 by 2050, and many older workers have delayed retirement due to the financial woes of the current economic recession (Pew Research Center, 2009). Culture-wise, immigration is projected to slow, yet whites are predicted to constitute a minority of the American population by 2050 , with $31 \%$ of the population projected to be made up of Hispanics by 2050 (Roberts, 2009). Current metropolitan trends already reflect this tidal change, where whites are currently a minority group in the New York City area (Roberts, 2011). Hence, the workforce is projected to become increasingly diverse. The Society for Human Resource Management (2011) finds that concerns about generational, religious, and disability differences will factor heavily into HR professionals' strategies for the foreseeable future. Possible shifts especially in the age 
and racioethnicity of workplace majority groups require that HR practitioners and scholars alike reevaluate what we think we know about diversity. For example, should workplace affinity groups be a way of retaining Hispanic workers when these workers may soon constitute the majority group in particular workplaces? And, from a theoretical standpoint, because many of our theories about diversity in American workplaces are predicated on the diverse group being in the minority, will new theories of power and dominance be necessary to understand in-group and out-group dynamics? Will white men retain power as a minority, and therefore will new theories which recognize the existence of a powerful minority group, as in the South African context, become necessary?

International workforce trends require a new way of studying and practicing $\mathrm{HR}$ as well. As Tung's (2008) research has pointed out, and the expatriate HRM literature has hinted at, most management studies fall prey to the fallacious assumption of cultural homogeneity both within nations and within subjects. Intranational variations in culture are commonplace as are individual, crossnational identities (as in the case of an AfricanAmerican woman living and working in South Africa). The diversity literature has been almost deaf to the realities of intersectionality (Calas, 2003). And the U.S. HRM literature in particular (respective of expatriate research) has had a decidedly Americentric workforce focus. Under a new, more reality-based paradigm, researchers will find it difficult to put workers into "neat and tidy" demographic groups for convenience samples. We propose that a shift to the individual, that is, individual identities a la the post-multiculturalism paradigm above, will be necessary. This shift to the individual is not meant to imply the end of systematic discrimination against particular groups, but rather a way of studying diversity that more accurately reflects the identities that workers hold for themselves.

Also on the international front, the American diversity literature must become more cognizant of the context in which workplace relations exists. For example, the concerns over 
European multiculturalism are embedded within a return to nationalism and traditionalism in many EU countries amidst increased immigration and the squeeze for limited resources, including jobs, housing, and social services. These external forces play a salient role in how individuals are treated in employment situations. While immigration is predicted to slow in the U.S. in coming years, HR leaders remain concerned about employees for whom English is a second language, the number of foreign-born workers, and documenting legal compliance in the employment of guest and foreign-born workers (SHRM, 2011). It is imperative that these HR issues are examined within the larger political context en route to understanding contemporary barriers to workplace equality.

\section{CONCLUSION}

From the Industrial Revolution unto present day, the plight of the racioethnic minority worker and the progression of the associated dominant ideologies of the time represent undeniable progress in the march toward workplace equality in the United States. From condoned discrimination to legislated equal opportunity to multiculturalism to presumed inclusion, diverse workers have experienced a degree of assimilation and social acceptance in U.S. workplaces. Yet, despite the current ideologies of inclusion and post-race, equality has not been achieved. In fact, we believe the historical exercise we have undertaken in this manuscript has revealed a fundamental trend in diversity ideologies over the years: The more things change, the more they actually stay the same. In many instances, a turn toward a new ideology actually meant a reversal in progress and/or a backlash against progress achieved, as in the case of fatigue with both equal opportunity and multiculturalism. As well, the backlash against immigrants and resultant elite nativism/nationalism of the turn of the last century in the U.S. is reminiscent of today's critics of multiculturalism in EU member nations. Relatedly, because of the dominant group's fear of the loss of power, resources, or social exclusion, as in the turn away from the ideologies of affirmative action and 
multiculturalism, over time terminologies have changed in a way that makes them benign and more palatable to all. While diversity terminologies have trended toward the socially innocuous, at the same time practice has become less focused on the real issues of reducing past and continued discrimination. For example, when equal opportunity turned toward diversity management, it became an ideology inclusive of all workers, with a focus more on the uniqueness of all and less on racism toward some. And the ideology of inclusiveness in effect represents a return to colorblindness, an idea introduced nearly 60 years ago.

While diversity terminology has changed many times over the years, the issues have not. Equality for workers from racioethnic minority groups has remained an elusive goal, yet a goal that has not been abandoned essentially because it has not been achieved. In this vein it is perhaps no surprise that, despite moving toward ideologies of inclusion and post-race today, the HRM research remains rather firmly entrenched in establishing how best to manage diverse groups and how to make the business case to decision-makers. Said another way, after well over a century of research and practice, researchers still appear unsure of how to achieve social cohesion and assimilation and how to sell the need to continue the effort. From our historical analysis, we conclude that diversity ideologies, often overlapping and sometimes recycled, will continue to be advanced in the United States until the true, often unpleasant issues surrounding racioethnic diversity in the workplace, namely racism and its manifestations, are directly confronted in organizations. 


\section{References}

Ahmed, S. 2007. The language of diversity. Ethnic and Racial Studies, 30: 235-256.

Alibhai-Brown, Y. 2000 (May 23). Moving beyond multiculturalism in practice. Daily Telegraph. http://fpc.org.uk/publications/after-multiculture.

Amason, A.C. 1996. Distinguishing the effects of functional and dysfunctional conflict on strategic decision making: Resolving a paradox for top management teams. Academy of Management Journal, 39: 123-48.

Arrendondo, P. 1996. Successful diversity management initiatives: A blue print for planning and implementing. Thousand Oaks, CA: Sage.

Avery, D.R. 2011. Support for diversity in organizations: A theoretical exploration of its origins and offshoots. Organizational Psychology Review, 1: 239-256.

Banton, M. 1998. Racial theories. Cambridge, MA: Cambridge University Press.

Bayroff, A. 1966. Test technology and equal employment opportunity. Personnel Psychology, 19: 35-39.

Bhagat, R. 1979. Black-white ethnic differences in identification with the work ethic: Some implications for organizational integration. Academy of Management Review, 4: $381-391$

Boehm, V. 1977. Differential prediction-A methodological artefact. Journal of Applied Psychology, 62: 146-154.

Bonilla-Silva, E. 2006. Racism without racists. Lanham, MD: Rowman \& Littlefield Publishers, Inc.

Brodkin, K. 1998. How Jews became white folks and what that says about race in America. New Brunswick, NJ: Rutgers University Press.

Calás, M.B. 2003. Reframing “democracy, diversity and multiculturalism:” Towards a 
transnational organizational discourse. Symposium paper presented at the Annual Meetings of the Academy of Management, Seattle, WA.

Caliguiri, P. 1999. The ranking of scholarly journals in international human resource management. International Journal of Human Resource Management, 10: 515519.

Citrin, J., Sears, D.O., Muste, C., \& Wong, C. 2001. Multiculturalism in American public opinion. British Journal of Political Science, 31: 247-275.

Commons, J. 1907. Races and immigrants in America. New York: MacMillan.

Cooke, B. 2003. The denial of slavery in management studies. Journal of Management Studies, 40: 895-918.

Cox, T.H. 2004. Problems with research by organizational scholars on issues of race and ethnicity. Journal of Applied Behavioral Science, 40: 124-145.

Cox, T.H., \& Blake, S. 1991. Managing cultural diversity: Implications for organizational competitiveness. Academy of Management Executive, 5: 45-56.

Deaux, K., Reid, A., Martin, D., \& Bikmen, N. 2006. Ideologies of diversity and inequality: Predicting collective action in groups varying in ethnicity and immigrant status. Political Psychology, 27: 123-146.

Delton, J. 2007 (Summer). Before the EEOC: How management integrated the workplace. Business History Review, 81: 269-295.

Dipboye, R. L. 1985. Some neglected variables in research on employment discrimination in appraisals. Academy of Management Review, 10: 116-127.

Dobbin, F. \& Sutton, J. R. 1998. The strength of a weak state: The rights revolution and the rise of human resource management divisions. American Journal of Sociology, 104: 441-476.

Dowd, J. 1902. Negro labor in factories (Southern Workman, 30; November: 588-590). In 
P. S. Foner and R. L. Lewis, (Eds.) 1980. The black worker from 1900 to 1919, pp.

4-6. Philadelphia: Temple University Press.

Dulebohn, J. H., Ferris, G. R., \& Stodd, J. T. 1995. The history and evolution of human resource management. In G. R. Ferris, Sherman D. Rosen, and D. T. Barnum (Eds.) Handbook of Human Resource Management, pp. 18-41. Cambridge, MA: Blackwell Publishers.

Edelman, L. 1990. Legal environments and organizational governance: The expansion of due process in the American workplace. American Journal of Sociology, 95: 14011440.

Edelman, L. B., Abraham, S. E. \& Erlanger, H. S. 1992. Professional construction of the legal environment: The inflated threat of wrongful discharge doctrine. Law and Society Review, 26: 47-83.

Ely, R.J., \& Thomas, D.A. 2001. Cultural diversity at work: The effects of diversity perspectives on work group processes and outcomes. Administrative Science Quarterly, 46: 229-273.

Federal Glass Ceiling Commission. 1995. Good for business: Making full use of the nation's human capital. Washington, DC: Government Printing Office.

Fluehr-Lobban, C. 2006. Race and racism: An introduction. Lanham: Rowman Altamira. Foner, P. S., \& Lewis, R. L. 1980. The black worker from 1900 to 1919. Philadelphia, PA: Temple University Press.

Foner, P. S., \& Lewis, R. L. 1981. The era of post-war prosperity and the Great Depression 1920-1936. Philadelpahia, PA: Temple University Press.

Foner, P. S., \& Lewis, R. L. 1989. Black workers: A documentary history from colonial times to the present times. Philadelphia, PA: Temple University Press.

Gavin, J., \& Ewen, R. 1974. Racial differences in job attitudes and performance-some 
theoretical considerations and empirical findings. Personnel Psychology, 17: 455464.

Gilroy, P. 1998. Race ends here. Ethnic and Racial Studies, 21: 839-847.

Gilroy, P. 2001. After the great white error . . . the great black mirage. Transformation, 47: $28-49$.

Glazer, N. 1997. We are all multiculturalists now. Cambridge, MA: Harvard University Press.

Grossman, R.J. 2000. Is diversity working? HR Magazine, 45: 47-50.

Gutman, H. 1973. Work, culture and society in industrializing America, 1815-1919. American Historical Review, 78: 531-588.

Haney-Lopez, I. F. 2005. Race and colorblindness after Hernandez and Brown. ChicanoLewis Law Review, 25: 61-76.

Hoobler, J.M. 2005. Lip service to multiculturalism: Docile bodies of the organization. Journal of Management Inquiry, 14: 49-56.

Hoobler, J.M., Basadur, T., \& Lemmon, G. 2007. Management of a diverse workforce: Meanings and practices. Journal of Equipment Lease Financing, 25(1), Winter issue.

Hopkins, D. 1980. Models for affirmative action planning and evaluation. Management Science, 26: 994-1006.

Hughes, E. C. 1946. The knitting of racial groups in industry. American Sociological Review, 11: 512-19.

Hunter, J.E., Schmidt, F.L., \& Hunter, R. 1979. Differential validity of employment tests by race: A comprehensive review and analysis. Psychological Bulletin, 85: 721-735. Ignatiev, N. 1995. How the Irish became white. New York: Routledge. Johns, G. 2001. Commentary: In praise of context. Journal of Organizational Behavior, 
22: $31-42$.

Johnston, W.B. \& Packer, A.E. 1987. Workforce 2000: Work and workers for the twentyfirst century. Indianapolis, IN: Hudson Institute.

Joshi, A., Liao, H, \& Roh, H. 2011. Bridging domains in workplace demography research: A review and reconceptualization. Journal of Management, 37: 521-552.

Kaufman, B. E. 1993. The origins and evolution of the field of industrial relations. Ithaca, NY: ILR Press.

Kaufman, B. E. 2008. Managing the human factor: The early years of human resource management in American industry. Ithaca, NY: Cornell University Press.

Kelly, E., \& Dobbin, F. 1998. How affirmative action became diversity management. American Behavioral Scientist, 41: 960-85.

King, D. 2005. Facing the future: America's post-multiculturalist trajectory. Social Policy \& Administration, 39: 116-129.

Kochan, T., Bezrukova, K., Ely, R., Jackson, S., Joshi, A., Jehn, K., Leonard, J., Levine, D., \& Thomas, D. 2003. The effects of diversity on business performance: Report of the Diversity Research Network. Human Resource Management, 42: 3-21

Kurowski, L.L. 2002. Cloaked in culture and veiled in diversity: Why theorists ignored early U.S. workforce diversity. Journal of Management History, 40: 183-191.

Laird, P. W. 2006. Pull: Networking and success since Benjamin Franklin. Cambridge, MA: Harvard University Press.

Landy, F. J., \& Farr, S. L. 1980. Performance rating. Psychological Bulletin, 87: 72-107. Linnehan, R., \& Konrad, A.M. 1999. Diluting diversity: Implications for intergroup inequality in organizations. Journal of Management Inquiry, 8: 399-414.

Literary Digest. 1900 (December). The labor question in the South. 22: 763-764. Lynch, F.R. 1997. The diversity machine: The drive to change the "White male 
workplace.” New York: Free Press.

McKee, J. B. 1993. Sociology and the race problem: The failure of a perspective.

Champaign, IL: University of Illinois Press.

Milliken, F. J., \& Martins, L. L. 1996. Searching for common threads: Understanding the multiple effects of diversity in organizational groups. Academy of Management Review, 21: 402-33.

Mowday R.T., \& Sutton, R.I. 1993. Organizational behavior: linking individuals and groups to organizational contexts. Annual Review of Psychology, 44: 195-229

Newman, J.M., \& Krzytofiak, F. 1979. Self-reports versus unobtrusive measures: Balancing method variance and ethical concerns in employment discrimination research. Journal of Applied Psychology, 64: 2-85.

Nkomo, S. 1997. The ideology of managing diversity. Symposium paper presented at the Annual Meetings of the Academy of Management, Boston, MA.

Nkomo, S., \& Stewart, M. 2006. Diverse identities. In S. Clegg, W.R. Nord, \& S. Hardy (Eds.), Handbook of Organization Studies, $2^{\text {nd }}$ edition (pp. 520-540). New York: Sage.

Omi, M., \& Winant, H. 1986. Racial Formation in the United States: From the 1960s to the 1980s. New York: Routledge \& Kegan Paul Inc.

Pew Research Center. 2009. Recession turns a graying office grayer. http://pewsocialtrends.org/2009/09/03/recession-turns-a-graying-office-grayer.

Plaut, V.C. 2002. Cultural models of diversity in America: The psychology of difference and inclusion. In R. Shweder, M. Minow, \& H. R. Markus (Eds.), Engaging cultural differences: The multicultural challenge in liberal democracies (pp. 365-395). New York: Russell Sage Foundation Press.

Plaut, V.C. 2010a. Diversity science: Who needs it? Psychological Inquiry, 21: 168-174. 
Plaut, V.C. 2010b. Diversity science: Why and how difference makes a difference.

Psychological Inquiry, 21: 77-99.

Plaut, V.C., Thomas, K.M., \& Goren, M.J. 2009. Is multiculturalism or color blindness better for minorities? Psychological Science, 20: 444-446.

Putnam, R.D. 2000. Bowling alone: The collapse and revival of American community. New York: Simon \& Schuster.

Richeson, J.A., \& Nussbaum, R.J. 2004. The impact of multiculturalism versus colorblindness on racial bias. Journal of Experimental Social Psychology, 40: 417-423.

Roberson, Q.M. 2006. Disentangling the meanings of diversity and inclusion in organizations. Group \& Organization Management, 31: 212-236.

Roberts, S. 2009. Projections put Whites in minority in U.S. by 2050. NY Times. http://www.nytimes.com/2009/12/18/us/18census.html.

Roberts, S. 2011. Non-Hispanic Whites are now a minority in the 23-county New York region. NYTimes. http://www.nytimes.com/2011/03/28/nyregion/28nycensus.html.

Robinson, G., \& Dechant, K. 1997. Building a business case for diversity. Academy of Management Executive, 11: 21-31.

Roethlisberger, F.J. \& Dickson, W.J. 1939. Management and the worker. Cambridge, MA: Harvard University Press.

Scalia, J. 1995. Concurring opinion: Adarand Constructors, Inc. v. Pena, Certiorari to the United States Court of Appeals for the Tenth Circuit, No. 93-1841. Argued: January 17.

Seliger, M. 1976. Ideology and politics. London: Allen \& Urwin.

Shaeffer, R.G. 1980. Nondiscrimination in employment-And beyond. New York: Conference Board.

SHRM. 2011. Workplace forecast. Society for Human Resource Management. 
Shore, L.M., Chung-Herrera, B.G., Dean, M.A., Ehrhart, K. H., Jung, D. I., Randel, A.E. \& Singh, G. 2009. Diversity in organizations: Where are we now and where are we going? Human Resource Management Review, 19: 117-133.

Shore, L.M., Randel, A.E., Chung, B.G., Dean, M.A., Ehrhart, K.H., \& Singh, G. 2011. Inclusion and diversity in work groups: A review and model for future research. Journal of Management, 37: 1262-1289.

Sidanius, J., \& Pratto, F. 1999. Social dominance: An intergroup theory of social hierarchy and oppression. New York: Cambridge University Press.

Takaki, R. 1979. Iron cages: Race, culture in $19^{\text {th }}$ century America. New York: Alfred A. Knopf Inc.

Taranto, J. 2009. Obama's postracial America: Why stupid squabbles over race are a sign of progress. September 15. Wall Street Journal On-line. http://online.wsj.com/article/SB10001424052970203917304574414923099147990.ht $\mathrm{ml}$.

Tepstra, D., \& Larsen, M. 1985. A note on job type and applicant race as determinants of hiring decisions. Journal of Occupational Psychology, 53: 117-119.

Thompson, K. 2005. The early sociology of race and ethnicity. Sociology for the South or the Failure of Free Society, vol I. George Fitzhugh. Oxon: Routledge.

Tung, R. L. 2008. The cross-cultural research imperative: The need to balance cross-national and intra-national diversity. Journal of International Business Studies, 39: 41-46.

United Nations Environment Programme. 2009. Climate in peril. United Nations Environment Programme.

United States Industrial Commission. 1900. Research Report VII. Washington, D.C. Vallas, S.P. 2003. Rediscovering the color line within work organizations. The 'Knitting of Racial Groups' revisited. Work and Occupations, 30: 379-400. 
Van Dijk, T. 2000. Ideologies, racism, discourse: Debates on Immigration and ethnic issues. In J. ter Wal and M. Verkuyten (Eds.), Comparative perspectives on racism, (pp. 91-115). Surrey: Ashgate.

Van Knippenberg, D., \& Schippers, M. 2007. Work group diversity. Annual Review of Psychology, 58: 515-41.

Vertovec, S. 2010. Towards post-multiculturalism? Changing communities, conditions and contexts of diversity. International Social Science Journal, 61: 83-95.

Williams, K.Y., \& O’Reilly, C.A. III. 1998. Demography and diversity in organizations: A review of 40 years of research. In B.M. Staw \& L.L. Cummings (Eds.), Research in Organizational Behavior. Greenwich, CT: JAI Press.

Wrege, C.D., Greenwood, R.A., \& Hata, S. 1999. What we do not know about management history: Some categories of research and methods to uncover management history mysteries. Journal of Mangaement History, 5: 414-424.

Wrege, C.D. \& Perroni, A.G. 1974. Taylor's pig-tale: A historical analysis of Frederick W. Taylor's pig-iron experiment. Academy of Management Journal, 17: 6-27.

Zanoni, P., Jannsens, M., Benschop, Y., \& Nkomo, S. 2010. Unpacking diversity, grasping inequality: Rethinking difference through critical perspectives. Organization, 17: 929.

Zeidel, R.F. 2004. Immigrants, Progressives and exclusion politics: The Dillingham Commission 1900-1927. DeKalb: Northern Illinois University Press. 